\title{
Archives and special collections: 24/7
}

Hard to imagine the reading room of an archival and special collections repository standing at the nexus of our modern information age? At the Bancroft Library on the University of California-Berkeley Campus, these worlds truly collide. Poised next to researchers viewing leaves of Tebtunis papyri, manuscripts of Mark Twain, and letters of Gold Rush pioneers are the latest versions of laptop computers and the rampant but silent scurry of mice-the computer kind across mousepads. While an occasional researcher approaches printed catalog cards, far more enjoy the powerful search engines of online catalogs and databases to discover and view centuries old treasures.

Archives and special collections repositoties have now embraced the distinct advantages provided by information technologies, opening new doors for researchers to our voluminous collections of letters, diaries, manuscripts, and photographs. A fourth-grade class in Fresno and a graduate seminar at North Carolina may now both enjoy a new-found access to the images and words of Japanese-American internment victims during World War II, to student protesters of the Free Speech Movement in the 1960 s, or pioneers in bioscience and biotechnology during the 1970s. Access to digital information on rare and unique materials certainly seems to breed increased scholarly inquiry. The once popular telephone number for the Bancroft Reference Desk is now outdone by our e-mail reference address: bancref@library.berkeley.edu

The Reference Desk remains a portal for inquiry, as scholars and students focus, refine, and reconfigure their research projects through conversations with Bancroft staff. Fear of locating no relevant information in our holdings sometimes gives way to dismay at finding long lists of publications, manuscript collections, oral histories, and pictorial materials. For undergraduates, such as the hundreds who visit Bancroft in a given semester through their introductory History $7 \mathrm{~B}$ course, the journey is as important as the result. Increasingly, faculty members wish to have undergraduates experience the full spectrum of academic research, and Bancroft staff works with Teaching Library staff to coordinate this effort.

The Edward H. Heller Reading Room is a place where time may stand still, but scholarly inquiry never stops. As our typical day continues after the 9:00 a.m. opening, some 40 to 60 researchers, including undergraduate and graduate students, faculty of all ranks, visiting scholars from around the globe, and a variety of local and regional visitors, may appear. All this activity keeps the public services staff quite busy, including staff members who help register patrons. Staff services include: retrieving and shelving the many books, cartons, and materials requested by researchers; reference desk help for researchers navigating our online catalogs and printed resources; photocopying documents and reproducing photographs and images; and maintaining security and comfort for those who work and study in the Reading Room.

Teaching and instruction is a large part of Bancroft operations these days. In one of many examples, Bancroft Director Charles B. Faulhaber regularly offers Spanish 246 (Spanish Paleography) in one of our seminar rooms, making extensive use of printed and manuscript collections. The educational value of all that the Bancroft Libtary collects, preserves, and provides access to eirher in manuscript, print, or digital format supersedes all others. Although Bancroft remains closed and secure throughout the night, digital collections and online resources remain open and ready for business. Statistics for a typical week indicate that the Bancroft Web site received 10,111 hits, and that 5,915 of those Web visitors proceeded to explore online information for an extended time period. Bancroft is now a 24/7 online information resource, because the scholarly research process literally never ceases! One can only wonder what changes the next decade, the next year, or even the next week will bring.

-William Brown, coordinator of research and instruction, University of California-Berkeley, Bancroft Library, wbrown@library. berkeley, edu 